UDC 581.5:574.3]:57.045(234.421.1:477)

\title{
CHANGES IN VITALITY OF POPULATIONS OF RARE ARCTIC-ALPINE PLANT SPECIES IN HIGH MOUNTAIN PART OF THE UKRAINIAN CARPATHIANS UNDER THE INFLUENCE OF CLIMATIC FACTORS
}

\author{
R. M. Cherepanyn \\ Vasyl Stefanyk Precarpathian National University \\ 57, Shevchenko St., Ivano-Frankivsk 76018, Ukraine \\ e-mail: roman.cherepanyn@gmail.com
}

Cherepanyn R. M. Changes in vitality of populations of rare arctic-alpine plant species in high mountain part of the Ukrainian Carpathians under the influence of climatic factors. Studia Biologica, 2019: 13(1); 117-128 • DOI: https://doi.org/10.30970/sbi.1301.582

Changes in vitality of populations of rare arctic-alpine plant species (Anemone narcissiflora, Bartsia alpina, Saussurea alpina, Pedicularis oederi) of the Ukrainian Carpathians in the highland habitats under the influence of climatic factors were analyzed. Population vitality was investigated according to individual diagnostic parameters vitality of individuals, population vitality index, population quality index, and according to population parameters - density, total and effective quantity.

It was established that during 2010-2018, the vitality of the Saussurea alpina population on the Shpyci Mount remained average. The uneven distribution of individuals on habitat area and complex spatial structure of the population loci positively affected the vitality of the Saussurea alpina population on Mt. Shpyci. Individuals of different vitality levels and heterogeneous structure according to morphometric parameters were observed in population.

A decrease in population vitality and flowering gaps of generative individuals were observed in Saussurea alpina population on Mt. Petros due to climatic changes, intrapopulation processes, and anthropogenic stress.

The upper locus of the only population of Pedicularis oederi in Ukraine between Brebeneskul and Munchel mountains underwent transformation, in particular, drying out of suitable habitats due to climate change. The population also underwent periodic anthropogenic influence as a result of grazing, which leads to unstable demographic trends - decrease in the habitat area, number of adults and generative individuals, coefficient of generative reproduction etc.

(C) 2019 R.M. Cherepanyn. Published by the Ivan Franko National University of Lviv on behalf of Біологічні Студії / Studia Biologica. This is an Open Access article distributed under the terms of the Creative Commons Attribution License (http://www.budapestopenaccessinitiative.org/ and Creative Commons Attribution 4.0 License), which permits unrestricted reuse, distribution, and reproduction in any medium, provided the original work is properly cited.

ISSN 1996-4536 (print) • ISSN 2311-0783 (on-line) • Біологічні Студії / Studia Biologica • 2019 • Том 13/№1 • С. 117-128 
A vitality of the Anemone narcissiflora population behind Nesamovyte Lake remains high. During 2011-2018, the total population size increased due to subsenile and senile individuals, while a number of the pregenerative individuals and the effective population size decreased.

An increase in ontogenesis polyvariability, density of individuals, recovery index, number of pregenerative individuals and decrease in number of generative individuals are observed in Bartsia alpina population on Mt. Rebra due to overgrowth of the habitat by highdensity plants and shrub species (Juncus trifidus, Vaccinium myrtillus and Rhododendron myrtifolium). Clonal reproduction was intensified. Rejuvenation of populations and a increase in pregenerative phases duration, in particular - immature and virginile periods, were observed.

Keywords: vitality, populations, arctic-alpine species, climate change, Ukrainian Carpathians

\section{INTRODUCTION}

Population viability is a general characteristics of self-recovery, settlement and preservation of evolutionary perspectives - remains an important aspect in studying of changes that occurr in populations of rare plant species under the influence of climatic factors. The problems of populations viability and vitality were considered by many researchers who developed various approaches [3, 4, 18-20, 22]. A number of works were devoted to assessing the populations viability of rare plant species in the Ukrainian Carpathians [1, 26, 15, 24, 29]. Detailed study of mechanisms that ensure population viability remains relevant in future. Establishing their vitality is an integral characteristic that reflects current state of populations on the basis of the most important individual and group parameters (structure, dynamics, evolution and reproduction) [16].

Vitality can be defined as an indicator of individuals or populations state that is characterized by qualitative development parameters and quantitative growth parameters [21]. In particular, the vitality of populations depends on the age spectrum, reproductive efficiency, population structure due to the vitality of individuals etc. The populations vitality depends on spatial-functional integrity, natural and anthropogenic influence [2, 12, 13]. Diagnostic indicators that characterize the vitality of small populations are intrapopulation diversity, habitat area, spatial structure, population dynamics, seed productivity, density of individuals, total and effective quantity $[7,8,14,26]$.

The aim of this study was to analyze changes in the populations vitality of rare arctic-alpine plant species in the high mountain part of the Ukrainian Carpathians under the influence of climate changes. Arctic-alpine species play an important role in ecosystems of Arctic and sub-Arctic regions and in mountains of the Northern Hemisphere. These species also serve as model organisms in study related to the analysis of effects of climate change on the environment.

\section{MATERIALS AND METHODS}

The following rare arctic-alpine plant species in high mountain part of the Ukrainian Carpathians were selected in order to analyze changes in populations vitality under the influence of climate changes: Anemone narcissiflora L., Bartsia alpina L., Saussurea alpina (L.) DC., Pedicularis oederi Vahl.

ISSN 1996-4536 (print) • ISSN 2311-0783 (on-line) • Біологічні Студії / Studia Biologica • 2019 • Том 13/№1 • C. 117-128 
A study was conducted by stationary and route methods in the Chornohora massif. The area of the habitat, height above sea level, density and number of individuals were determined for populations. Population density was determined by a number of individuals per area, in terms of $1 \mathrm{~m}^{2}$ [10]. Age structure of populations was determined on the basis of age groups ratio of individuals [9, 17, 25].

The coefficient of generative reproduction in populations was defined as a ratio of number of generative individuals to adult individuals. A recovery index in populations was calculated as a relation in number of pregenerative individuals to generative individuals [23].

Population vitality was studied according to individual diagnostic parameters - individuals' vitality, population vitality index, population quality index; and according to population diagnostic parameters - density, total and effective quantity etc. The vitality of individuals was studied according to a traditional three-level graduation of individuals' vitality in vitality classes. We differentiated the vitality of individuals to "high" $(c<Q)$, "average" (c $=Q$ ) and "low" (c>Q), using the population quality index $(Q)$, calculated as: $Q=0.5(a+b)$, where "a", "b" and "c" are the frequencies of individuals of high, average and low vitality [24, 26-28]. Also, we used the index of coenopopulations vitality (IVC), developed for rare plant species, for analysis of population vitality. It was calculated as:

$$
\text { IVC }=1 / N \sum_{i=1}^{N} x i / X i
$$

where $x i$ - is the average value of the $i$-th sign in the population, $X i-$ is the average value of the $i$-th sign for all populations and $N-$ is the number of signs [4, 11].

The names of plant species are given according to "Identification key for plants of the Ukrainian Carpathians" and "The determinant of higher plants of Ukraine" $[5,6]$.

\section{RESULTS AND DISSCUSION}

The population of Saussurea alpina on the south-east slopes of Mt. Shpyci (Chornohora massif) at the altitude of 1840-1860 m above sea level consists of two loci and grows in rocky plant communities (alliance - Oxytropido-Elynion, associations - Caricetum sempervirentis and Thymo-Festucetum amethystinae) which change not significantly under influense of climate factors. The vitality of the population remains average during 2010-2018 (Table 1). The total area of the Saussurea alpina population is $300 \mathrm{~m}^{2}$. The total population quantity is about 350 adults, the effective population quantity increased from 80 generative individuals in 2010 to 120 - in 2018. In particular, the number of generative individuals increases from 29 pcs. to $61 \mathrm{pcs}$. in the first loci at $1860 \mathrm{~m}$ a.s.l. An increase in the number of generative individuals from 50 to 60 pieces was observed in the second locus at $1840 \mathrm{~m}$ a.s.l. The number of adult individuals in the first and second loci was 100 and 250 pieces, respectively. The density of individuals reached 15-20 pieces per $1 \mathrm{~m}^{2}$. The coefficient of generative reproduction has increased from 19 to $34 \%$ over the period of study, while the recovery index has decreased from 3.3 to 1.7 .

A number of generative individuals and the coefficient of generative reproduction increased due to a transition of a group of individuals from the virginile to the generative stage of ontogenesis. A reduction of the recovery index is due to the dominance of clonal reproduction in the population and a decrease in number of suitable sites for seeds germination, because of their overgrowth by the highdensity species (Carex sempervirens Vill.) (Fig. 1).

ISSN 1996-4536 (print) • ISSN 2311-0783 (on-line) • Біологічні Студії / Studia Biologica • 2019 • Том 13/№1 • C. 117-128 
Table 1. Characteristics of the vitality of population of Saussurea alpina (L.) DC.

Таблиця 1. Характеристика життєвості популяції Saussurea alpina (L.) DC.

\begin{tabular}{|c|c|c|c|c|c|c|c|}
\hline \multirow{2}{*}{\multicolumn{2}{|c|}{$\begin{array}{l}\text { Habitat, exhibition, } \\
\text { altitude ( } m \text { a.s.I.) }\end{array}$}} & \multicolumn{3}{|c|}{$\begin{array}{l}\text { Percentage of individuals in } \\
\text { populations by the level of vitality, } \%\end{array}$} & \multirow{3}{*}{$\begin{array}{c}\mathbf{Q} \\
18.0\end{array}$} & \multirow{3}{*}{$\begin{array}{l}\text { IVC } \\
0.8\end{array}$} & \multirow{2}{*}{$\begin{array}{l}\text { Vitality of the } \\
\text { population }\end{array}$} \\
\hline & & high, a & average, $b$ & low, c & & & \\
\hline \multirow{2}{*}{$\begin{array}{l}\text { Shpyci, } \\
\text { SE }\end{array}$} & $\begin{array}{l}1860 \mathrm{~m} \\
\text { (locus 1) }\end{array}$ & 6.8 & 29.2 & 64.0 & & & \multirow{2}{*}{ average } \\
\hline & $\begin{array}{l}1840 \mathrm{~m} \\
\text { (locus 2) }\end{array}$ & 24.2 & 45.7 & 30.1 & 34.9 & 1.1 & \\
\hline
\end{tabular}

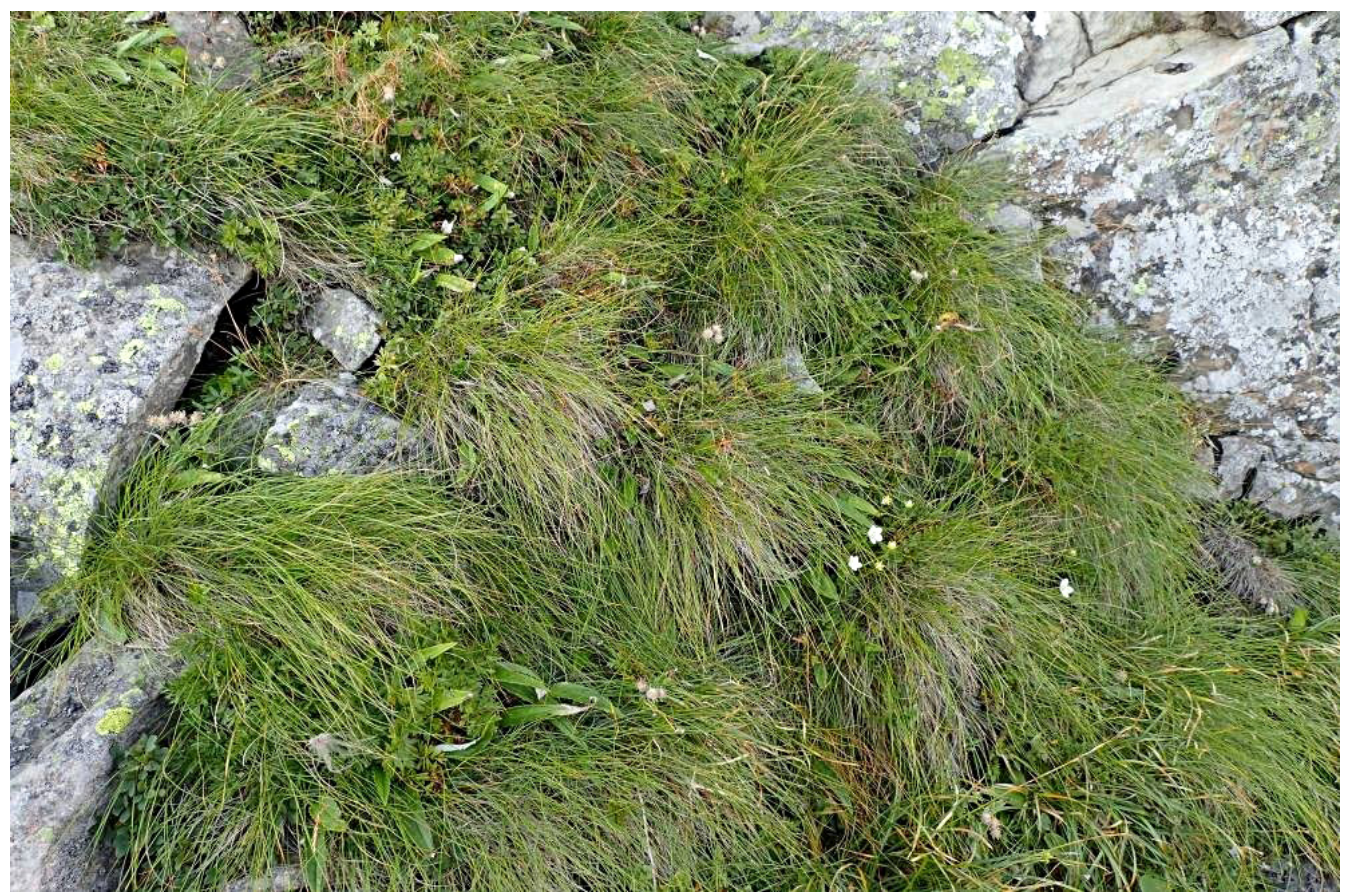

Fig. 1. Rocky coenosis of the Saussurea alpine (L.) DC. population on Mt. Shpyci (Chornohora massif), being overgrowth by highdensity species (Carex sempervirens Vill.)

Рис. 1. Скельні угруповання популяції Saussurea alpine (L.) DC. на горі Шпиці (Чорногірський масив), що заростають щільнодернинними видами (Carex sempervirens Vill.)

The uneven distribution of individuals on the habitat area and complex spatial structure of the population loci positively affected the vitality of the Saussurea alpina population on Mt. Shpyci. The individuals of different vitality levels and heterogeneous structure according to morphometric parameters were observed in the population (Table 2, 3).

A decrease in population vitality and flowering gaps of generative individuals were observed in Saussurea alpina population on the north-eastern slope of Mt. Petros at $1820 \mathrm{~m}$ a.s.I. which grows in conditions of rocky coenoses. In particular, since 2010, there was a sharp decrease in number of flowering individuals. In 2009, 60 blooming individuals were detected in the population however, only 5 blooming individuals were

ISSN 1996-4536 (print) • ISSN 2311-0783 (on-line) • Біологічні Студії / Studia Biologica • 2019 • Том 13/№1 • С. 117-128 
Table 2. Analysis of population of Saussurea alpina (L.) DC. by signs of vitality Таблиця 2. Аналіз популяції Saussurea alpina (L.) DC. за ознаками життєвості

\begin{tabular}{|c|c|c|c|c|c|c|c|c|c|c|}
\hline \multirow{3}{*}{\multicolumn{2}{|c|}{$\begin{array}{l}\text { Habitat, } \\
\text { exhibition, } \\
\text { altitude } \\
\text { (m a.s.I.) }\end{array}$}} & \multicolumn{9}{|c|}{ Parameters } \\
\hline & & \multicolumn{6}{|c|}{ individual } & \multicolumn{3}{|c|}{ population } \\
\hline & & 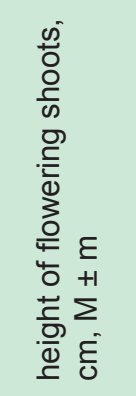 & 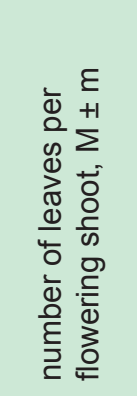 & 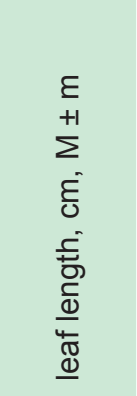 & 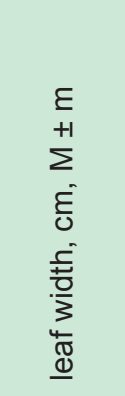 & 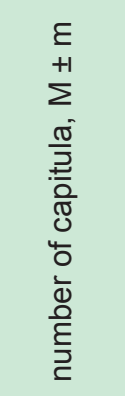 & 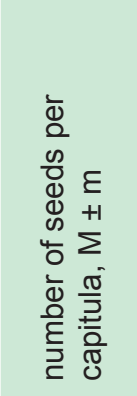 & 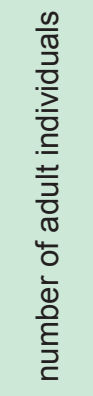 & 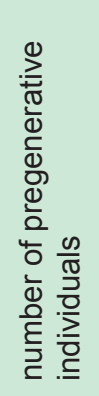 & 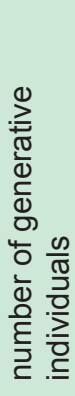 \\
\hline \multirow{4}{*}{ 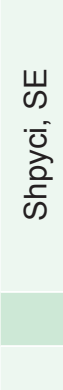 } & 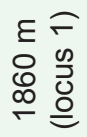 & $18.2 \pm 3.8$ & $6.5 \pm 1.1$ & $7.6 \pm 1.4$ & $2.1 \pm 0.3$ & $3.8 \pm 1.3$ & $19.3 \pm 1.2$ & 103 & 55 & 61 \\
\hline & 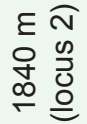 & $21.5 \pm 3.5$ & $14.5 \pm 2.0$ & $11.2 \pm 2.5$ & $2.2 \pm 0.6$ & $8.2 \pm 2.8$ & $23.5 \pm 1.9$ & 250 & 150 & 60 \\
\hline & & \multicolumn{9}{|c|}{ Average of parameters for all locus } \\
\hline & & 19.8 & 10.5 & 9.4 & 2.1 & 6.0 & 21.4 & 176.5 & 102.5 & 60.5 \\
\hline
\end{tabular}

Table 3. A distribution of individuals in population of Saussurea alpina (L.) DC. by the vitality

Таблиця 3. Розподіл особин у популяції Saussurea alpina (L.) DC. за життєвістю

\begin{tabular}{|c|c|c|c|c|c|c|c|c|}
\hline \multirow{2}{*}{\multicolumn{2}{|c|}{$\begin{array}{l}\text { Habitat, } \\
\text { exhibition, } \\
\text { altitude } \\
\text { (m a.s.I.) }\end{array}$}} & \multirow[b]{2}{*}{ Vitality } & \multicolumn{6}{|c|}{$\begin{array}{l}\text { Number of individuals according to } \\
\text { diagnostic parameters, } \%\end{array}$} \\
\hline & & & 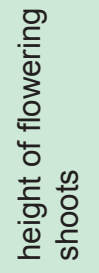 & 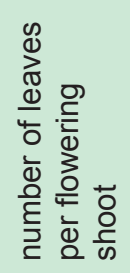 & 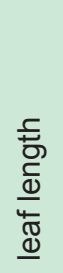 & $\begin{array}{l}\frac{5}{ \pm} \\
. \frac{0}{3} \\
\underline{4} \\
\mathbb{\Phi} \\
\underline{\Phi}\end{array}$ & 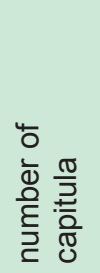 & 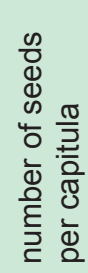 \\
\hline \multirow{6}{*}{$\begin{array}{l}山 \\
\omega \\
\overline{0} \\
\frac{\widehat{a}}{c} \\
\frac{1}{\omega}\end{array}$} & \multirow{3}{*}{$\begin{array}{l}\varepsilon \text { Г } \\
\varnothing \stackrel{0}{0} \\
\infty \\
\infty\end{array}$} & high & 9 & 0 & 0 & 0 & 0 & 31 \\
\hline & & average & 41 & 0 & 34 & 42 & 11 & 47 \\
\hline & & low & 50 & 100 & 66 & 58 & 89 & 22 \\
\hline & \multirow{3}{*}{ 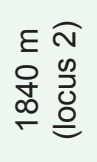 } & high & 56 & 32 & 12 & 10 & 31 & 5 \\
\hline & & average & 34 & 25 & 71 & 42 & 39 & 63 \\
\hline & & low & 10 & 43 & 17 & 48 & 30 & 32 \\
\hline
\end{tabular}

ISSN 1996-4536 (print) • ISSN 2311-0783 (on-line) • Біологічні Студії / Studia Biologica • 2019 • Том 13/№1 • C. 117-128 
counted in the following years. In 2018, 6 blooming individuals were observed. The population is subjected periodically stressful influences through the grazing of the sheep during the vegetation season that causes trampling of the habitat. The number of adult and pregenerative individuals were also reduced from 340 adults in 2009 to 300 in 2018, and from 255 pregenerative individuals in 2009 to 200 in 2018 . The questions of whether such changes are related to climatic factors and intrapopulation processes or only with anthropogenic stress require further studies.

The upper locus of the only population in Ukraine of Pedicularis oederi in between Brebeneskul and Munchel mountains located on a wet meadow on a south-west slope at $1955 \mathrm{~m}$ a.s.I. underwent transformation, in particular, drying out of suitable habitats due to climate change (Table 4). The population also underwent periodic anthropogenic influence as a result of grazing. The locus consists of two fragments are located at a distance of about $20 \mathrm{~m}$ of each other.

\section{Table 4. Population parameters of Pedicularis oederi Vahl}

\section{Таблиця 4. Популяційні параметри Pedicularis oederi Vahl}

\begin{tabular}{|c|c|c|c|c|c|c|c|c|c|}
\hline \multirow[b]{2}{*}{$\begin{array}{l}\text { Habitat, } \\
\text { exhibition, } \\
\text { altitude } \\
\text { (m a.s.I.) }\end{array}$} & \multirow[b]{2}{*}{ Year } & \multicolumn{8}{|c|}{ Parameters of population vitality } \\
\hline & & 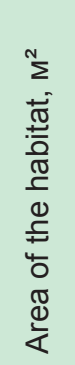 & 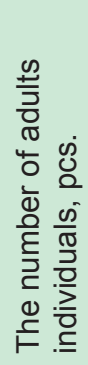 & 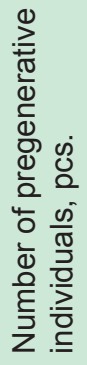 & 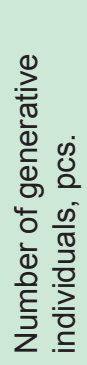 & 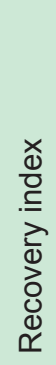 & 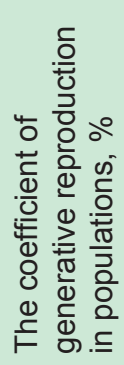 & 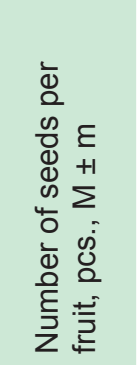 & 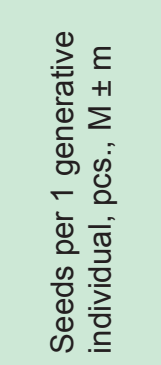 \\
\hline \multirow{3}{*}{$\begin{array}{l}\text { Between } \\
\text { Brebeneskul } \\
\text { and Munchel } \\
\text { mountains, } \\
\text { SW, } 1955 \text { m }\end{array}$} & 2011 & 200 & 250 & 140 & 70 & 2 & 28 & $15.6 \pm 1.3$ & $179.4 \pm 1.4$ \\
\hline & 2017 & 125 & 150 & 110 & 20 & 5.5 & 13.3 & $17.4 \pm 1.1$ & $200.1 \pm 2.4$ \\
\hline & 2018 & 125 & 150 & 70 & 90 & 0.7 & 60 & $13.1 \pm 1.8$ & $150.6 \pm 2.1$ \\
\hline
\end{tabular}

In 2011, the area of the first fragment was $150 \mathrm{~m}^{2}$, the area of the $2 \mathrm{nd}$ fragment $50 \mathrm{~m}^{2}$. In this habitat, the total quantity of individuals was 250 adults (150 in the first fragment and 100 in the second), the effective number was 70 generative individuals (40 - in the first fragment and 30 - in the second). The density of generative individuals in the population ranged from 2 to 7 per $1 \mathrm{~m}^{2}$, vegetative individuals $-4-6$ per $1 \mathrm{~m}^{2}$, seedlings - 4-6 per $1 \mathrm{~m}^{2}$. Immature and juvenile individuals, as well as a small proportion of senile and subsenile individuals (up to $10 \%$ ) were observed in the population. The height of the generative shoots were from 10 to $18 \mathrm{~cm}$, the number of fruits on the generative shoots are from 8 to 15 pieces. The coefficient of generative reproduction was $28 \%$, the recovery index equaled 2 in the upper loci of Pedicularis oederi population.

The area of the first and second fragments of the upper locus of the Pedicularis oederi population decreased significantly as a result of drying out of the habitat in 2017 (Fig. 2). In particular, the area of the first fragment is $90 \mathrm{~m}^{2}$, thus, decreased by $40 \%$, the area of the second fragment is $35 \mathrm{~m}^{2}$, thas, decreased by $30 \%$. Also, the total number of individuals was decreased by $40 \%$, and the effective number of individuals was

ISSN 1996-4536 (print) • ISSN 2311-0783 (on-line) • Біологічні Студії / Studia Biologica • 2019 • Том 13/№1 • С. 117-128 
decreased by $70 \%$. In particular, the total number were 150 adults individuals (100 in the first fragment and 50 - in the second one), the effective number is 20 generative individuals (15 - in the first fragment and 5 - in the second one). The number of subsenile and senile individuals increases (up to $30 \%$ ) and the density of generative individuals decreases (1-3 per $\left.1 \mathrm{~m}^{2}\right)$ in population. The coefficient of generative reproduction was $10-15 \%$, the recovery index was 5.5 .

Pedicularis oederi propagates only by seeds, therefore, the populations vitality depends on the efficiency of generative reproduction and the area of suitable habitats. During the vegetation season in 2018 a sufficient humidification of the habitat, significantly increasing number of flowering individuals (60 pieces in the first fragment and 30 pieces - in the second), increasing the coefficient of generative reproduction to $60 \%$ are observed in the upper loci of Pedicularis oederi population. Unstable demographic trends in the population - flowering outbreaks and flowering decline, a significant fluctuation in number of pregenerative individuals and the recovery index (Table 4) due to dependence of populations' self-maintenance and self-recovery primarily on substrate moisture and availability of suitable locus for germination. Further existence of the upper locus of the population may be at risk under the conditions of habitat drying out and overgrown.

Fig. 2. Drying out of the substrate in the Pedicularis oederi Vahl habitat between Brebeneskul and Munchel mountains due to climatic changes

Рис. 2. Підсихання субстрату в оселищі Pedicularis oederi Vahl між горами Бребенескул і Мунчель унаслідок кліматичних змін

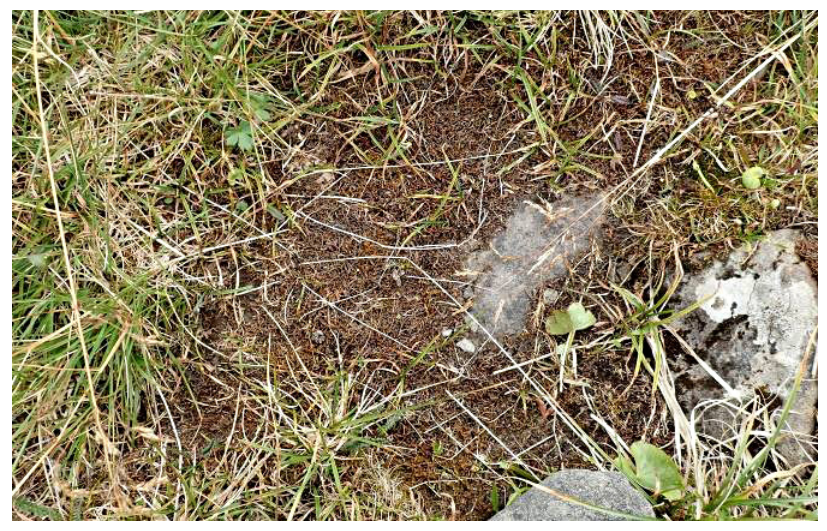

The Anemone narcissiflora population on the south-west slope behind Nesamovyte lake is located at an altitude of $1700-1800 \mathrm{~m}$ a.s.l. in rock and meadow phytocoenoses conditions, in particular, in Saxifrago-Festucetum versicoloris and Thymo-Festucetum amethystinae associations. The population belongs to normal type according to the age structure (Table 5). The location of individuals is compact-diffuse in the habitat. The coefficient of generative reproduction varies within 40-60\%, which indicates high population vitality. The height of generative individuals in the populations is $26-31 \mathrm{~cm}$. The number of generative shoots on a generative individual from 3 to 8 pieces. The density can reach 4-6 adults per $1 \mathrm{~m}^{2}\left(2-4\right.$ generative individuals per $\left.1 \mathrm{~m}^{2}\right)$ in the population behind the Nesamovyte lake. Seed growth was detected in the population. The number of individuals in generative group is higher than one and a half times the number of individuals in pregenerative group. The population vitality is high in this habitat. Demographic parameters of population changed slightly during 2011-2018. The total number has increased due to subsenile and senile individuals. The number of pregenerative individuals and the effective number of population have decreased (Table 5).

ISSN 1996-4536 (print) • ISSN 2311-0783 (on-line) • Біологічні Студії / Studia Biologica • 2019 • Том 13/№1 • С. 117-128 
Table 5. Population parameters of Anemone narcissiflora L.

Таблиця 5. Популяційні параметри Anemone narcissiflora L.

\begin{tabular}{|c|c|c|c|c|c|c|c|c|c|}
\hline \multirow[b]{2}{*}{$\begin{array}{l}\text { Habitat, } \\
\text { exhibition, } \\
\text { altitude } \\
\text { (m a.s.I.) }\end{array}$} & \multirow[b]{2}{*}{ Year } & \multicolumn{8}{|c|}{ Parameters of population vitality } \\
\hline & & 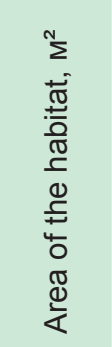 & 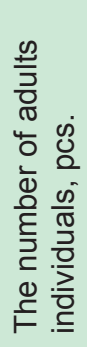 & 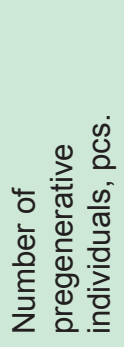 & 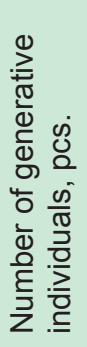 & 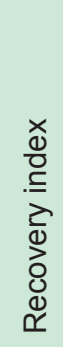 & 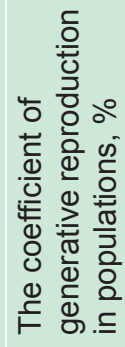 & 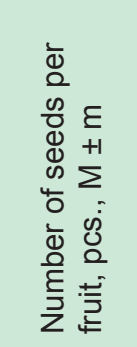 & 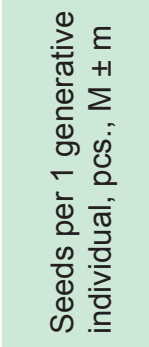 \\
\hline \multirow{2}{*}{$\begin{array}{l}\text { Beside the } \\
\text { Nesamovyte lake, } \\
\text { SW, } 1700-1800 \mathrm{~m}\end{array}$} & 2011 & 20000 & 1900 & 750 & 1100 & 0.7 & 57.9 & $25.4 \pm 1.8$ & $130,9 \pm 5,5$ \\
\hline & 2018 & 20000 & 2100 & 600 & 900 & 0.6 & 42.8 & $23.4 \pm 1.8$ & $120.6 \pm 6.8$ \\
\hline
\end{tabular}

Population of Bartsia alpina on the Mt. Rebra is located on screes and characterized by the compact-diffuse distribution of individuals in the habitat. The population belongs to a normal type, with the left-side age spectrum (Table 6) and occurs in the community Cetrario-Festucetum airoidis (class Junceta trifidi) and in open phytocoenosis, actively overgrown in the plant communities edges by highdensity plants and shrub species (Juncus trifidus L., Vaccinium myrtillus L. Ta Rhododendron myrtifolium Schott \& Kotschy). This reduces the area of free niches for seeds germination (Fig. 3). The density of adults, pregenerative and generative individuals is 32,18 and 6 individuals per $1 \mathrm{~m} \mathrm{2}$, respectively, in the population on the Mt. Rebra. The coefficient of generative reproduction varies from 10.7 to $19.3 \%$. High values of individuals density and recovery index are due to the predominance of vegetative reproduction, which is intensified in the conditions of highdensity plant communities and overgrown of screes. Intensification of the polyvariability of the Bartsia alpina population ontogenesis is also observed in such conditions. A part of pregenerative and generative individuals is formed as a result of vegetative growth. Vegetative mobility of the individuals is $3-5 \mathrm{~cm}$ per year in the population.

Table 6. Population parameters of Bartsia alpina L.

Таблиця 6. Популяційні параметри Bartsia alpina L.

\begin{tabular}{|c|c|c|c|c|c|c|c|c|c|}
\hline \multirow[b]{2}{*}{$\begin{array}{l}\text { Habitat, exhibition, } \\
\text { altitude } \\
\text { ( } \mathrm{m} \text { a.s.I.) }\end{array}$} & \multirow[b]{2}{*}{ Year } & \multicolumn{8}{|c|}{ Parameters of population vitality } \\
\hline & & 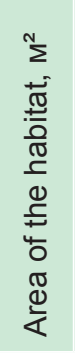 & 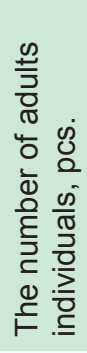 & 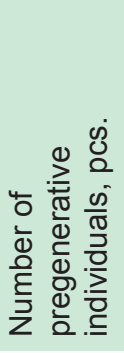 & 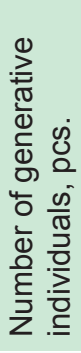 & 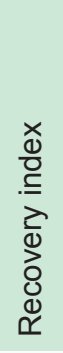 & 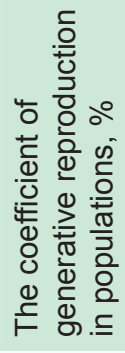 & 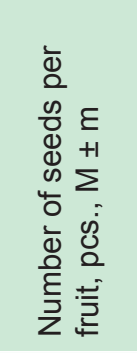 & 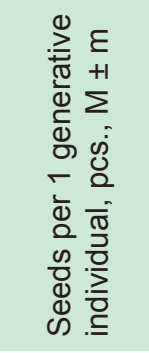 \\
\hline \multirow{2}{*}{ Rebra, NE, 1800 m } & 2011 & 200 & 1450 & 850 & 280 & 3.0 & 19,3 & $50.5 \pm 2.1$ & $200.0 \pm 6.5$ \\
\hline & 2018 & 150 & 1300 & 1000 & 150 & 6.6 & 11,5 & $43.3 \pm 2.4$ & $171.5 \pm 6.5$ \\
\hline
\end{tabular}

ISSN 1996-4536 (print) • ISSN 2311-0783 (on-line) • Біологічні Студії / Studia Biologica • 2019 • Том 13/№1 • C. 117-128 


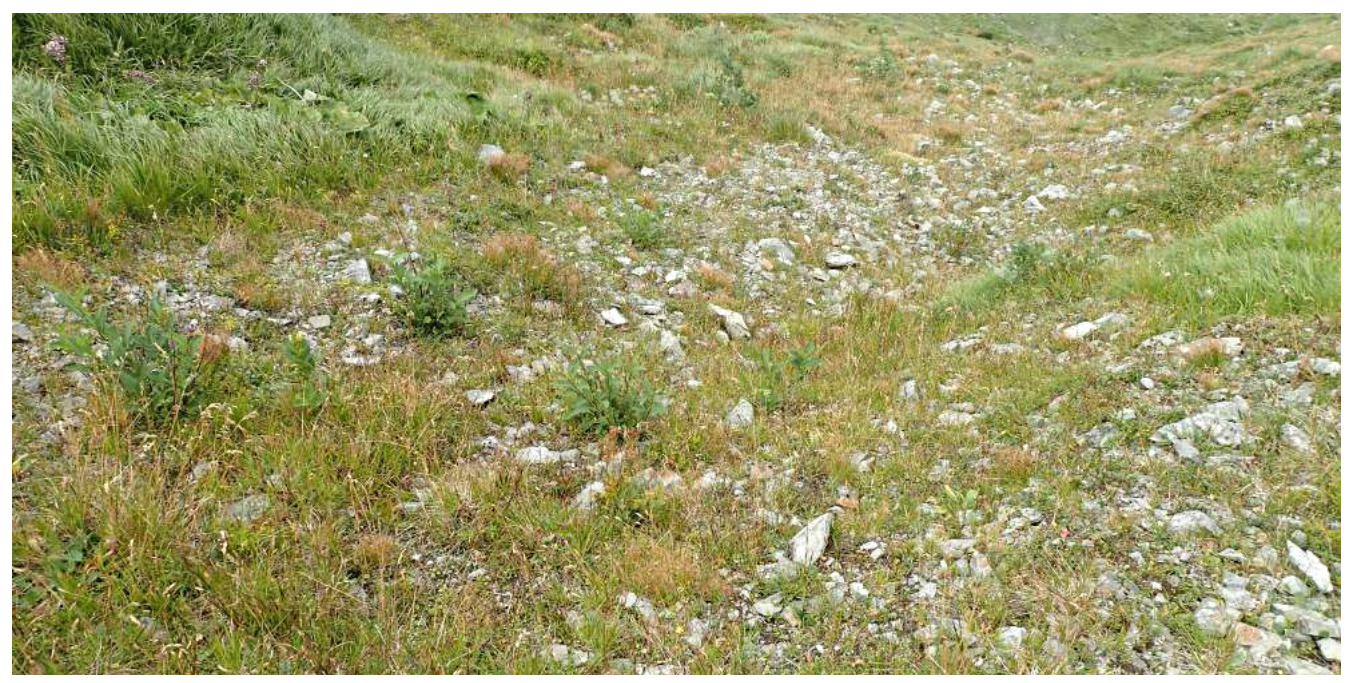

Fig. 3. Bartsia alpina L. habitat on the north-eastern slope of Mt. Rebra

Рис. 3. Оселище Bartsia alpina L. на північно-східному схилі гори Ребра

Rejuvenation of populations and an increasing of pregenerative phases duration, in particular - immature and virginile periods, are observed (Fig. 4). Such process has an important adaptive and evolutionary value, since a transition to the generative phase of ontogenesis occurs only in conditions favorable for this.

Fig. 4. Scheme of Bartsia alpina L. ontogeny: 1 - sequential passage of ontogenesis in open coenosis; 2 - rejuvenation of individuals during ontogenesis in conditions of habitats overgrowth

Pис 4. Схема онтогенезу Bartsia alpina L.: 1 - послідовне проходження онтогенезу у відкритих ценозах; 2 - омолодження особин під час онтогенезу в умовах заростання оселища

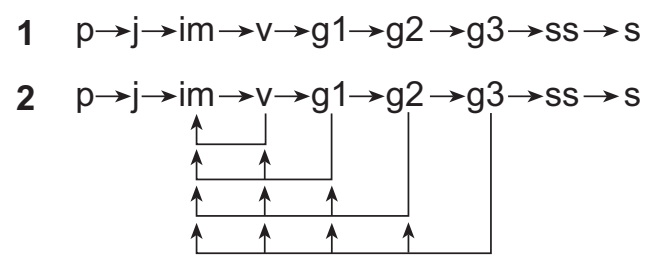

\section{CONCLUSIONS}

Changes in the vitality of populations of rare arctic-alpine plant species in a high mountain part of the Ukrainian Carpathians under the influence of climate factors are due mainly to the drying out of the substrate and competition as a result of successional processes - an increase in area of shrubs and highdensity plant coenoses.

Climate changes do not significantly affect the population vitality of rare arcto-alpine plant species of rocky coenoses of a high mountain part of the Ukrainian Carpathians. In particular, the number of generative individuals was increased and a recovery index was decreased due to a predominance of vegetative reproduction and overgrowth by Carex sempervirens, that leads to a decrease in number of suitable sites for seed germination in Saussurea alpina population on Mt. Shpyci. The vitality of Anemone narcissiflora population on the rocks behind the Nesamovyte Lake remains high, and the population vitality of Saussurea alpina on the Mt. Shpyci remains average.

Drying out of marshes and wet meadows leads to a decrease in the vitality of Pedicularis oederi population only in Ukraine. In particular, unstable demographic trends 
were observed in the population - the area of the habitat, the number of adults and generative individuals, the coefficient of generative reproduction have reduced.

The vitality parameters of Bartsia alpina population have been changed due to an overgrowth of the screes on Mt. Rebra by Juncus trifidus, Vaccinium myrtillus and Rhododendron myrtifolium. In particular, vegetative reproduction was increased as a result of a decrease in the area of free niches for generative reproduction. This leads to polyvariability of ontogenesis, an increase of the recovery index and a number of the pregenerative individuals, as well as a decrease in number of generative individuals.

\section{ACKNOWLEDGMENTS}

Publication is based on studies supported by the grant of the State Fund for Fundamental Research of Ukraine, No $\Phi 76 / 9-2018$.

1. Bagley O.V. Study of viability of populations of Saussurea porcii in the Ukrainian Carpathians. Nature reserves in Ukraine, 2008; 14(2): 54-56. (In Ukrainian)

2. Bagley O.V., Danylyk I.M. Ecological and biological characteristics of fragmentation populations of Saussurea porcii Degen (Asteraceae) in the Ukrainian Carpathians. Scientific Bulletin of UNFU, 2009; 19(4): 67-71. (In Ukrainian)

[Google Scholar]

3. Boer P.J. On the survival of populations in a heterogeneous and variable environment. Oecologia, 1981; 50: 39-53.

[Google Scholar]

4. Bystrushkin A.G. Comparative analysis of different methods for determining the vitality of cenopopulations on the example of Rubus idaeus L. In: Species and population - strategies of life: collection of materials of the IX All-Russian population seminar (part 2). Ufa, 2006: 45-48. (In Russian)

[Google Scholar]

5. Chopyk V.I. (Ed.) Identification key for plants of Ukrainian Carpathians. Kiev: Naukova dumka, 1977. 435 p. (In Ukrainian)

[Google Scholar]

6. Dobrochaeva D.N, Kotova M.I., Prokudin Yu.N. et al. (Eds.) The determinant of higher plants of Ukraine. Kiev: Naukova Dumka, 1987. 548 p. (In Russian)

[Google Scholar]

7. Garcia M. Life history and population size variability in a relict plant. Different routes towards long-term persistence. Diversity and Distributions, 2008; 14: 106-113.

[DOI: https://doi.org/10.1111/j.1472-4642.2007.00429.x; Google Scholar]

8. García M., Picó F., Ehrlén J. Life span correlates with population dynamics in perennial herbaceous plants. American Journal of Botany, 2008; 95(2): 258-262

[DOI: https://doi.org/10.3732/ajb.95.2.258; Google Scholar]

9. Gilyarov A.M. Population ecology. Moscow: Moscow University Publishing House, 1990. 192 p. (In Russian)

[Google Scholar]

10. Hutchinson G.E. An introduction to population ecology. New-Haven: Vale Univ. Press, 1978. 260 p.

[Google Scholar]

11. Ishbirdin A.R. Adaptive morphogenesis and ecological-cenotic strategies for the survival of herbaceous plants. In: Methods of population biology: reports of the VII All-Russian population seminar (part 2). Syktyvkar, 2004: 113-120. (In Russian) [Google Scholar]

12. Kobiv Y. Response of rare alpine plant species to climate change in the Ukrainian Carpathians. Folia Geobot, 2017; 52: 217-226

[DOI: https://doi.org/10.1007/s12224-016-9270-z; Google Scholar]

ISSN 1996-4536 (print) • ISSN 2311-0783 (on-line) • Біологічні Студії / Studia Biologica • 2019 • Том 13/№1 • С. 117-128 
13. Kobiv $Y$. Trends in population size of rare plant species in the alpine habitats of the Ukrainian Carpathians under cimate change. Diversity, 2018; 10(62): 1-12.

[DOI: https://doi.org/10.3390/d10030062; Google Scholar]

14. Kyyak $V$. Characteristics of structure and vitality of small populations of rare and endemic plant species in the Carpathian Mountains. Visnyk of Lviv Univ. Biology Series, 2002; 29: 93-101. (In Ukrainian)

15. Kyyak V.H. Evaluation criteria for the state and recruitment ability of small populations of rare highmountain Carpathian plant species. Scientific notes of the State Natural History Museum, 2012; 28: 41-50. (In Ukrainian) [Google Scholar]

16. Kyyak V.H. Vitality as an integral indicator of plant population state. Studia Biologica, 2014; 8(3-4): 273-284. (In Ukrainian)

[DOI: https://doi.org/10.30970/sbi.0803.364; Google Scholar]

17. Markov M.V. Population biology of plants (educational-methodical manual). Kazan: Publishing house of Kazan University, 1986. 110 p. (In Russian) [Google Scholar]

18. Matthies $B$. The genetic and demographic conseqences of habitat fragmentation for plants: examples from declining grassland species. Bundesamt für Naturschutz, Bonn. Schriftenr. Vegetationskunde, 2000; 32: 129-140. [Google Scholar]

19. Matthies D., Bräuer I., Maibom W., Tscharntke T. Population size and the risk of local extinction: empirical evidence from rare plants. Oikos, 2004; 105: 481-488.

[DOI: https://doi.org/10.1111/j.0030-1299.2004.12800.x; Google Scholar]

20. Menges E.S. Population viability analysis for an endangered plant. Conservation Biology, 1990; 4: 41-62.

[DOI: https://doi.org/10.1111/j.1523-1739.1990.tb00267.x; Google Scholar]

21. Mirkin B.M., Rosenberg G.S. Vitality. In: Mirkin B.M., Rosenberg G.S. Glossary Dictionary of Modern Phytocoenology. Moscow: Nauka, 1983. 133 p. (In Russian) [Google Scholar]

22. Reed J. M., Mills L.S., Dunning J.B. et al. Emerging issues in population viability analyses. Conservation biology, 2002; 16(1): 7-19.

[DOI: https://doi.org/10.1046/j.1523-1739.2002.99419.x; Google Scholar]

23. Tsaryk Y., Kyyak V., Dmytrah R. et al. Generative reproduction of plant populations in the high mountain part of the Ukrainian Carpathians as a sign of their viability. Visnyk of Lviv University. Biolog. Ser, 2004; 36: 50-56. (In Ukrainian) [Google Scholar]

24. Tsaryk J.V., Zhilyaev G.G., Kyyak V.G. et al. Viability of plant populations of highlands of the Ukrainian Carpathians. Tzaryk J. (Ed.). Lviv: Mercator, 2009. 172 p. (In Ukrainian) [Google Scholar]

25. Zaugolnova L.B. Population as a system of a superorganismal level. Coenopopulations of plants. Moscow: Nauka, 1988. P. 5-13. (In Russian)

26. Zhilyaev G.G. Viability of populations of plants. Lvov, 2005. 304 p. (In Russian) [Google Scholar]

27. Zlobin Yu.A. Principles and methods for studying coenotic plant populations. Kazan: Kazan University Press, 1989. 146 p. (In Russian) [Google Scholar]

28. Zlobin Yu.A. Theory and practice of assessing the vital composition of plant cenopopulations. Bot. Journal, 1989; 74(6): 769-784. (In Russian) [Google Scholar]

29. Zlobin Yu.A., Kirilchuk K.S., Tikhonova O.M., Melnik T.I. Interconditionality of forming vegetative and generative sphere of plants: a method of canonical correlations. Ukr. Botan. Journ, 2007; 64(2): 206-217. (In Ukrainian)

[Google Scholar] 


\section{ЗМІНИ ЖИТТЄВОСТІ ПОПУЛЯЦІЙ ДЕЯКИХ РАРИТЕТНИХ АРКТО-АЛЬПІЙСЬКИХ ВИДІВ РОСЛИН ВИСОКОГІР'Я УКРАЇНСЬКИХ КАРПАТ ПІД ВПЛИВОМ КЛІМАТИЧНИХ ЧИННИКІВ}

\section{P. М. Черепанин}

Прикарпатський національний університет імені Василя Стефраника вул. Шевченка, 57, Івано-Франківськ 76018, Україна e-mail: roman.cherepanyn@gmail.com

Проаналізовано зміни життєвості популяцій раритетних аркто-альпійських видів рослин (Anemone narcissiflora, Bartsia alpina, Saussurea alpina, Pedicularis oederi) Українських Карпат у високогірних оселищах під впливом кліматичних фракторів. Життєвість популяцій досліджено за індивідуальними діагностичними параметрами (життєвістю особин, індексом життєвості популяції, індексом якості популяцій) та популяційними ознаками (щільністю, загальною й ефективною чисельністю тощо).

Встановлено, що протягом 2010-2018 років життєвість популяції Saussurea alpina на горі Шпиці залишається середньою. Нерівномірність розподілу особин по площі оселища та складна просторова структура популяційних локусів позитивно впливають на життєвість популяції Saussurea alpina на горі Шпиці. У популяції наявні особини різного рівня життєвості, спостерігається гетерогенна структура за морфометричними показниками.

У популяції Saussurea alpina на горі Петрос виявлено зниження життєвості та пропуски цвітіння, що пов'язане з кліматичними факторами, внутрішньопопуляційними процесами й антропогенним навантаженням.

Верхній локус єдиної в Україні популяції Pedicularis oederi між горами Бребенескул і Мунчель зазнає трансформації внаслідок змін клімату, зокрема - пересихання придатних оселищ. Популяція також зазнає періодичного антропогенного впливу внаслідок випасання, що призводить до зменшення площі оселища, кількості дорослих і генеративних особин, коефіцієнта генерування.

Життєвість популяції Anemone narcissiflora за озером Несамовите є високою. Протягом 2011-2018 років у популяції збільшилася загальна чисельність завдяки субсенільним і сенільним особинам, а кількість прегенеративних особин та ефективна чисельність популяції зменшилася.

У популяції Bartsia alpina на горі Ребра спостерігається зростання поліваріантності онтогенезу, щільності особин, індексу відновлення, чисельності прегенеративних особин і зменшення кількості генеративних особин унаслідок заростання оселища щільнодернинними та чагарниковими видами (Juncus trifidus, Vaccinium myrtillus та Rhododendron myrtifolium). Водночас посилюється вегетативне розмноження, відбувається омолодження популяцій і збільшення тривалості прегенеративних фраз, зокрема, іматурної та віргінільної.

Ключові слова: життєвість, популяції, аркто-альпійські види, зміни клімату, Українські Карпати

Одержано: 30.12 .2018

ISSN 1996-4536 (print) • ISSN 2311-0783 (on-line) • Біологічні Студії / Studia Biologica • 2019 • Том 13/№1 • С. 117-128 